\title{
Distribution, abundance and density estimates of franciscanas, Pontoporia blainvillei (Cetacea: Pontoporiidae), in Babitonga bay, southern Brazil
}

\author{
Marta J. Cremer ${ }^{1} \&$ Paulo C. Simões-Lopes ${ }^{2}$ \\ ${ }^{1}$ Laboratório de Nectologia, Departamento de Ciências Biológicas, Universidade da Região de Joinville. Caixa Postal 110, \\ 89240-000 São Francisco do Sul, Santa Catarina, Brasil. E-mail: marta.cremer@univille.net \\ ${ }^{2}$ Laboratório de Mamíferos Aquáticos, Departamento de Ecologia e Zoologia, Universidade Federal de Santa Catarina. \\ Caixa Postal 5102,88040-970 Florianópolis, Santa Catarina, Brasil. E-mail: lamaqs/@ccb.ufsc.br
}

\begin{abstract}
Pontoporia blainvillei (Gervais \& d'Orbigny, 1844) is threatened throughout its distribution. The species can be found year-round in the Babitonga bay estuary $\left(26^{\circ} 02^{\prime}-26^{\circ} 28^{\prime} \mathrm{S}\right.$ and $\left.48^{\circ} 28^{\prime}-48^{\circ} 50^{\prime} \mathrm{W}\right)$, in the north coast of the state of Santa Catarina, Brazil. Boat surveys were conducted in order to evaluate its abundance and density between 2000 and 2003. Sampling was random and stratified, with 46 transects in five subareas, comprising a total area of $160 \mathrm{~km}^{2}$. Data collection was conducted following the linear transect method with distance sampling. A total of $1174.7 \mathrm{~km}$ was scanned and 38 groups were observed. Franciscanas were not uniformly distributed in Babitonga bay. Group size ranged from one to 13 animals (mean $\pm S D=5.02 \pm 3.62$ ). Model 1 (Half-Normal) showed the best fit to the data. The estimated population size was 50 animals and the density was 0.32 individuals $\mathrm{km}^{-2}$. Density estimates evaluated in the sub-areas where franciscanas occurred resulted in a density of 0.46 individuals $\mathrm{km}^{-2}$. Monitoring this population is of considerable importance due to the constant threats that this species faces in this bay.

KEY WORDS. Concentration area, distance sampling, group size.
\end{abstract}

RESUMO. Distribuição e estimativas de abundância e densidade de franciscanas, Pontoporia blainvillei (Cetacea: Pontoporiidae), na baía da Babitonga, sul do Brasil. Pontoporia blainvillei (Gervais \& d'Orbigny, 1844) ocorre ao longo de todo o ano no estuário da baía da Babitonga, no litoral norte de Santa Catarina, sul do Brasil. Foram realizadas amostragens com o objetivo de obter informações sobre sua abundância e densidade populacional nesta área entre os anos de 2000 e 2003. A amostragem foi aleatória e estratificada, com 46 transecções estabelecidas em cinco grandes sub-áreas, compreendendo $160 \mathrm{~km}^{2}$. A coleta de dados foi conduzida utilizando o método de transecções lineares com amostragem de distância. Foram percorridos 1174,7 km e 38 grupos foram registrados. As franciscanas não apresentaram uma distribuição uniforme na baía da Babitonga. $O$ tamanho de grupo variou de um a 13 animais $(5,02 \pm 3,62)$. O Modelo 1 (Meio-Normal) promoveu o melhor ajustamento dos parâmetros. A população foi estimada em 50 animais e a densidade foi de 0,32 indivíduos $\mathrm{km}^{-2}$. A estimação de densidade calculadas apenas para as sub-áreas de ocorrência (áreas 2,3 e 5; total de $101 \mathrm{~km}^{2}$ ) resultou em uma densidade de 0,46 indivíduos $\mathrm{km}^{-2}$. O monitoramento desta população é de grande importância devido às constantes ameaças que a espécie está sujeita na baía.

PALAVRAS-CHAVE. Amostragem de distâncias; área de concentração; tamanho de grupo.

Coastal cetacean species are affected by human activities and this problem has increased in the last years. Some human activities pose significant threats to the viability of some populations, as the case of Pontoporia blainvillei (Gervais \& D'Orbigny, 1844). Throughout the distribution of this species, accidental mortality in fishery operations is the main threat (PRADERI et al. 1989, Pinedo 1994, Siciliano 1994, Rosas et al. 2002).

Pontoporia blainvillei is restricted to the southeastern Atlantic Ocean. Its northern limit of occurrence is at Itaúnas, state of Espírito Santo, Brazil (18²5'S, 3042’W) (Siciliano 1994), and the southern limit is at Golfo Nuevo, Península Valdés, Argentina ( $42^{\circ} 35^{\prime} \mathrm{S}, 64^{\circ} 48^{\prime} \mathrm{W}$ ) (CRESPo et al. 1998). Data obtained from accidental captures in fishing operations indicate that the occurrence area of the species is limited by the $30 \mathrm{~m}$ isobath along the coast (PINEDo et al. 1989). In Brazil, the species is considered "threatened" (IвAмa 2003), whereas the "The World Conservation Union" classifies it as "data deficient" (ReEves et al. 2003).

Its relatively small size, discrete surface behaviour, and dorsally brownish grey coloration, similar to the color of the water in its habitat, are factors that make its observation diffi- 
cult in the field (Cremer \& Simões-Lopes 2005). Trimble \& Praderi (2006) pointed out that differences in the franciscana's color along its distribution could indicate an adaptation to its particular environment. Franciscanas were successfully followed in the field only in two places along its distribution: Anegada bay (40³0'S), Argentina (Bordino et al. 1999, Bordino 2002) and Babitonga bay $\left(26^{\circ} 13^{\prime} S\right)$, state of Santa Catarina, Brazil (CREmer \& Simões-Lopes 2005). Most of the knowledge about the species has been gathered from stranded animals and from accidental captures in fishery operations.

In Babitonga bay, concentration areas were identified and the animals were monitored year-round (CREMER \& SiMÕES-LOPES 2005). Both franciscanas and estuarine dolphins (Sotalia guianensis Van Bénéden, 1864) occur in this area in broad sympatry (sensu BEARzi 2005) and their ranges show considerable spatial overlap. In Anegada bay, a coastal marsh zone in Argentina, franciscanas were more frequently observed during spring and summer, when the species is close to the shore (Bordino et al. 1999).

Abundance estimates have been considered a research priority for this species (REeves et al. 2003), but this information is scarce due to the inherent difficulties in observing franciscanas in nature. SECCHI et al. (2001) carried out a pilot study to estimate franciscana abundance from aerial surveys at the state of Rio Grande do Sul, Brazil, using line transects with distance sampling. The present study reports on distribution, abundance and density estimates of franciscanas in Babitonga bay, on the northern coast of the state of Santa Catarina, Brazil. There is currently a growing concern about habitat loss and degradation of this area, that represent direct and indirect threats to the franciscana population that lives there. This information will provide some guidance on evaluating the magnitude of these impacts on this franciscana population over time.

\section{MATERIAL AND METHODS}

\section{Study area}

Babitonga bay is located in the state of Santa Catarina, southern Brazil $\left(26^{\circ} 02^{\prime}-26^{\circ} 28^{\prime} \mathrm{S}\right.$ and $\left.48^{\circ} 28^{\prime}-48^{\circ} 50^{\prime} \mathrm{W}\right)$, encompassing an area of $160 \mathrm{~km}^{2}$ (Fig. 1). The bay is connected to the ocean through a $1.7 \mathrm{~km}$ wide channel. The maximum depth is $28 \mathrm{~m}$ in the main channel, with a mean depth of $6 \mathrm{~m}$, and many tidal flats. Although the estuary receives water flows from many rivers, it is considered a homogeneous estuary in its physical-chemical parameters (IBAMA 1998). There are many islands in the inner waters. Its borders consist of mangroves, rocky shores and muddy-sand beaches. On the west side, the bay receives a large amount of contaminants from the city of Joinville through the Saguaçú Lagoon and the Cubatão River. The Linguado Channel, in the southern region of the bay, was closed in 1938 and undergoes an intense process of siltation that affects the whole bay (Oliveira et al. 2006).

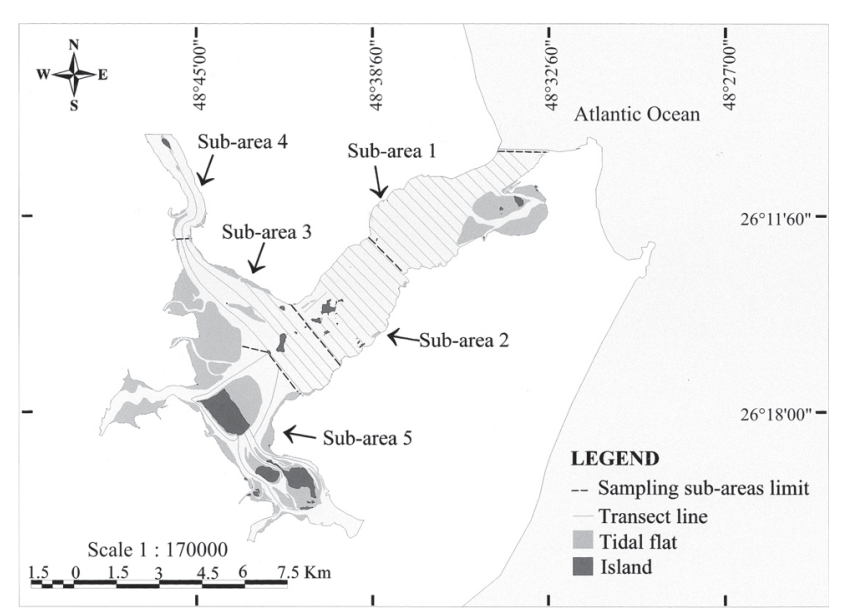

Figure 1. Location of the study area: Babitonga bay, southern Brazil, and sampling design used for Pontoporia blainvillei abundance and density estimates on boat transects.

\section{Sample design}

For the abundance estimates, we used the line transect method with distance sampling (BuCKLAND et al. 2001, THOMAs et al. 2002a). Surveys covered the entire study area. Transects were plotted on a digitized nautical chart (numbers 1804 and 1805 of the Diretoria de Hidrografia e Navegação; 1:28.000 scale) using Mapinfo $4.1 .2^{\circledR}$ (Fig. 1). Transects were projected transversally to the coastline whenever possible. However, the presence of islands and tidal flats in some locations required transects to be performed parallel to the coastline. A total of 46 transects were established, which were ca. $400 \mathrm{~m}$ apart when parallel. Transects were distributed in five sub-areas of different sizes, which were defined arbitrarily. Sub-area 1: comprises the channel that connects the bay to the ocean; highest depth in the bay (>20 m) $\left(42.94 \mathrm{~km}^{2}\right)$; sub-area 2: comprises the central region of the bay, including the inlet of São Francisco do Sul harbor $\left(25.24 \mathrm{~km}^{2}\right)$; sub-area 3: comprises the inner region of the estuary, where the main currents of the bay converge $\left(31.4 \mathrm{~km}^{2}\right)$; sub-area 4 : comprises the environment under highest influence of freshwater in the estuary, also impacted by the contaminants $\left(7.67 \mathrm{~km}^{2}\right)$; and sub-area 5: comprises the area of Linguado Channel, which receives the largest contaminated discharge in the bay $\left(52.9 \mathrm{~km}^{2}\right)$.

We stratified the sampling based on previous knowledge on the distribution of the population in Babitonga bay (CREMER $\&$ SIMÕEs-Lopes 2005). For each sampling interval (month or season - see explanation below), 50\% of the randomly defined established transects in each sub-area were covered, except for area 4 , where only one transect was available (Fig. 1). Adjacent transects were not covered when selected in the random transect drawings. Our previous experience showed that the animals were detected at a distance up to $200 \mathrm{~m}$, overlapping the visual fields. Each transect was considered as a replicate (BUCKLAND et al. 2001). 


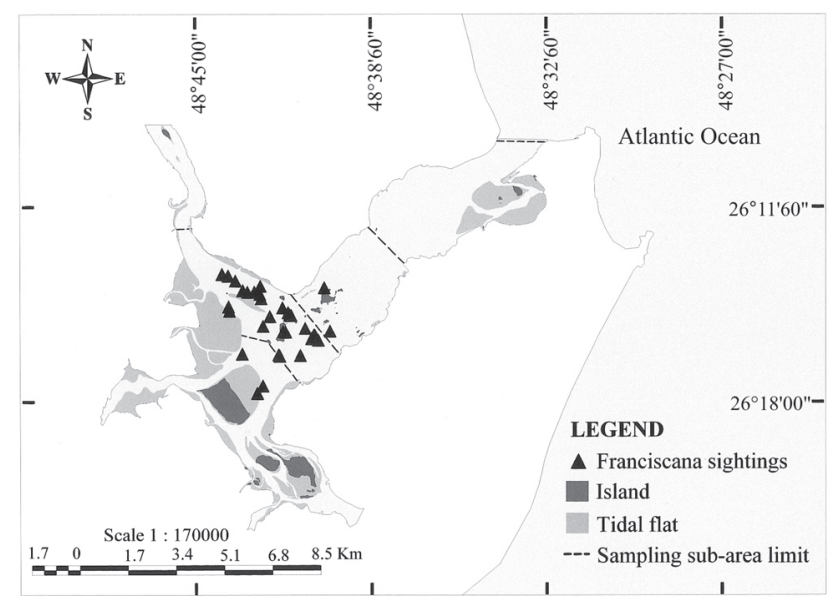

Figure 2. Distribution of Pontoporia blainvillei groups during boat transects in Babitonga bay between December 2000 and December 2003.

\section{Data collection}

Surveys were conducted in three periods. Between December 2000 and November 2001 (Period 1), we conducted monthly samplings, as we also did between January 2002 and December 2002 (without sampling in February and March) (Period 2). In 2003, the samplings were seasonal, extending from January to November (Period 3). A training period was conducted between October and November of 2000. During this period, 41 transects were completed and $143.3 \mathrm{~km}$ surveyed. Observers tested the estimate of radial distance considering floating bodies (buoys). At the same time, distance was measured by the pilot using reticulated binoculars for comparison. Franciscanas were also detected during the training period (five groups), but data were not used in the analysis. In all surveys, the same crew of four observers was maintained.

During the sampling period, two $5.5 \mathrm{~m}$ long vessels with a $40 \mathrm{HP}$ and a $60 \mathrm{HP}$ outboard engines were used. Each sampling was conducted with two observers, positioned at the bow of the vessel and a pilot responsible for the notes; each observer was responsible for scanning an angle of $90^{\circ}$ from the bow. The position of the observers was between 2.5 and $3 \mathrm{~m}$ above the water surface. Daily effort varied depending on environmental conditions. Samplings were carried out under calm sea (Beaufort sea state 0 to 1 ), mainly during morning periods, when wind influence is reduced. Poorer sea conditions were considered to be too limiting for the detection of the species. When sea condition became unfavorable, sampling was canceled and data discarded. Cruising speed was kept between 10 and $15 \mathrm{~km} / \mathrm{h}$, and the viewing angle in relation to the bow was measured using a large protractor positioned at the bow of the boat. The radial distance was estimated visually. In addition, geographical position (using GPS) and group size were recorded.
Our definition of "group" follows SHANe (1990), which establishes it as "any group of dolphins sighted in apparent association, moving in the same direction, and often, but not always, engaged in the same activity." Age-class differentiation was not considered due to the difficulty in determining the classes at distance, which could underestimate the number of offsprings. The term "population" was used here to describe the franciscanas recorded inside the Babitonga bay.

\section{Data analysis}

Data were analyzed using the program Distance $4.0^{\circ}$ (ТноMAS et al. 2002b). The criterion employed by the program to select the best-fitting model is the lowest AIC (Akaike Information Criterion) value. The probability of detection in the line transect was assumed to be equal to $1(\mathrm{~g}(0)=1)$ in this study. The fulfillment of this assumption was considered acceptable taking into consideration two factors: 1) reduced speed of the vessel (maximum speed of $15 \mathrm{~km} / \mathrm{h}$ ), and 2) ideal sea condition (Beaufort sea state 0 to 1 ). Two abundance and density values were estimated: 1) considering the total study area (= Babitonga bay), and 2) considering only the sub-areas used by franciscana. Group size was compared between sampling periods using ANOVA $(p=0.05)$. A distribution map was generated using the geographical positions of all survey records obtained in effort.

\section{RESULTS}

We spent 92 days, with 1,294.40 km conducted in effort along the three periods. Table I summarizes the information regarding the effort and counting.

Thirty-eight groups of P. blainvillei were registered, for a total 191 individuals. Group size varied from 1 to 13 individuals (mean $\pm \mathrm{SD}=5.02 \pm 3.6, \mathrm{CI}=95 \%$ ). However, the modal concentration was in groups of three individuals. The mean group size $(=5)$ did not differ between the sampling periods $\left(\mathrm{F}_{1,38}=0.5187, \mathrm{p}=0.963>0.05\right)$. Franciscanas were not uniformly distributed in Babitonga bay (Fig. 2). Groups were not detected in sub-areas 1 and 4, and the animals were concentrated in sub-area $3(\mathrm{n}=31)$. Sub-areas 2,3 and 5 , where the animals were registered, covered a total area of about $101 \mathrm{~km}^{2}$.

Table I. Line transect effort along three years for Pontoporia blainvillei abundance and density estimates in Babitonga bay, southern Brazil.

\begin{tabular}{ccc}
\hline Year & Days & Kilometers \\
\hline 2001 & 42 & 554.2 \\
2002 & 35 & 391.8 \\
2003 & 15 & 294.4 \\
\hline
\end{tabular}

The half-normal model without data adjustments was the best fit for perpendicular distance data in both analyses. The population density estimate for Babitonga bay was 0.32 indi- 
vidual $\mathrm{km}^{-2}(\mathrm{CI}=0.18-0.57)$, with a mean abundance of 50 individuals $(\mathrm{CI}=28-89, \mathrm{p}=0.05)(\% \mathrm{CV}=29.93)(\mathrm{AIC}=441.8)$. Considering only the sub-areas of franciscana occurrence $\left(=101 \mathrm{~km}^{2}\right)($ sub-areas 2, 3 and 5), the mean abundance was slightly lower, with 47 individuals $(\mathrm{CI}=26-84, \mathrm{p}=0.05)(\% \mathrm{CV}=29.61)$ $(\mathrm{AIC}=441.8)$. Mean density was higher with an estimation of 0.46 individual $\mathrm{km}^{-2}(\mathrm{CI}=0.26-0.82, \mathrm{p}=0.05)$. Table II summarizes the encounter rates, mean group size and the model parameters used. Figure 3 shows the distribution of perpendicular distances and the detection function adopted for the study area analysis.

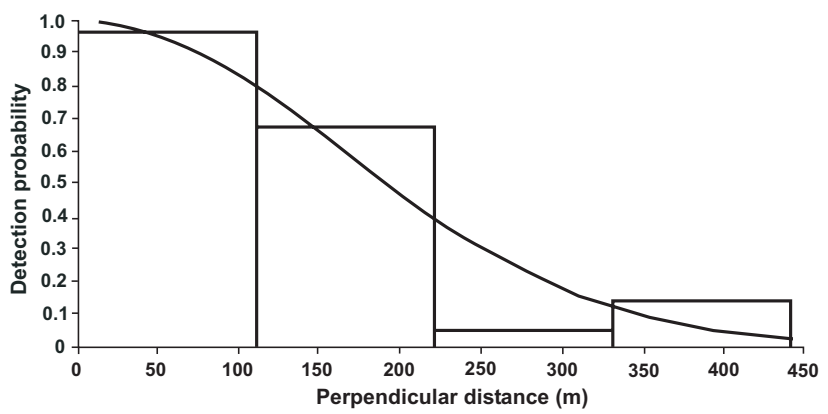

Figure 3. Frequency distribution of perpendicular distances of Pontoporia blainvillei sightings during line transects with distance sampling in Babitonga bay. The continuous line represents the best fitted function.

\section{DISCUSSION}

Three assumptions are considered essential for estimation of density and abundance using distance sampling method: 1) all animals on the trackline are detected; 2) the animals did not move in response to the research vessel; and 3) distances are measured accurately (Тномаs et al. 2002b). The first assumption was met, considering the low velocity of the boat during the transect and the good sea conditions inside the bay. We are confident, therefore, that any biases in detection of animals on the trackline were small. SECCHI et al. (2001) obtained franciscana abundance and density estimates for the coastal waters of Rio Grande do Sul State through aerial sampling $(150 \mathrm{~km} / \mathrm{h})$ and applied a correction factor of 0.358 . Some authors have pointed the difficulty in detecting the species with the use of motor boats (Bordino et al. 1999, SECCHI et al. 2001), and this may affects estimates of perpendicular distance from the trackline. Auditory sensitivity in cetaceans can be high but our present understanding of how these animals respond to sound is insufficient to allow predictions of behavioural responses (HiLdebrand 2005). Small boat traffic is frequent in the preferential area of franciscanas in Babitonga bay. It is possible that a reduction of responsiveness over time occurs due to the animals becoming used to this noise (HildEBRAND 2005), reducing the effect of our research boat during the surveys. So, we consider that the use of motorboats can be an applicable strategy to conduct population estimates, mainly for small cetaceans. Accurate measures of radial distance are difficult to obtain in the sea. It was very difficult to use reticulated binoculars to estimate the perpendicular distance, because of the bay characteristics (presence of islands and mountains). We sought to correct this bias with observers training in the beginning of the work. It is likely, therefore, that this assumption was violated and influenced our franciscana density and abundance estimate.

Burnham et al. (1980) pointed out the relevance of group size estimates. The precise counting of individuals in a group during transect sampling is difficult due to the small size and discrete behaviour of franciscana. Although the mean group size obtained in effort was of five individuals, the numerous opportunistic observations of the species in this area suggested that, in general, it occurs in greater groups, ranging from 15 to 20 individuals (CREMER \& SiMÕES-LOPES 2005). Groups of 10 to 17 individuals have been reported in literature (CRESPO et al. 1998, Di BeneditTo et al. 2001). It is probable that franciscana abundance was underestimated in Babitonga bay. Possibly, this influenced the data obtained by SECCHI et al. (2001), where the mean was lower (=1.16 individuals), considering that this was an aerial sampling. However, the mean group size was also very small in Anegada bay (mean $\pm \mathrm{SD}=2.8 \pm 1.3$ ) (Bordino et al. 1999). In addition to the sea conditions as limiting factor for the detection of the species in distance sampling, a reduced cloud cover was also considered a positive parameter for sightings.

Franciscanas showed a clumped dispersion pattern (sensu BEGON et al. 1996), with an obvious preference for some areas, as observed by CREMER \& Simões-Lopes (2005). This distribution pattern was similar to that observed for $S$. guianensis, sympatric in the bay (CREMer et al. 2004), but no interactions between the species were recorded during the present study. It is possible that franciscanas occur elsewhere in Babitonga bay, including movements in and out of the bay. Preferential areas can represent keyhabitats associated to the occurrence of important resources (mainly prey), so as indicated by some authors to explain the distribution of small cetacean populations in coastal areas (KARCZMARSKI et al. 2000, EDWARDS \& SCHNELL 2001). Environmental factors, whether involved or not in prey abundance can affect movement of coastal dolphin species, such as depth, sea floor relief and tide (Würsig \& WÜrsig 1980, Ballance 1992, KarcZMarsKi et al. 2000, Edwards \& Schnell 2001, Bordino et al. 1999, Bordino 2002). In Bahia Anegada, P. blainvillei sightings were seasonal and positively correlated with surface water temperature (BoRDINO et al. 1999). Studies indicated that the movements of franciscanas were not random inside Bahia Anegada and were significantly associated to tidal conditions (Bordino 2002).

The franciscana distribution in Babitonga bay indicated that human activities also influenced the species distribution. The animals were never seen near the harbor, as observed for S. guianensis in the same area (CRemer et al. 2004). Probably franciscanas are very sensitive to the disturbance caused by 
Table II. Estimated model parameters, density and abundance of Pontoporia blainvillei in Babitonga bay, southern Brazil.

\begin{tabular}{|c|c|c|c|c|c|c|c|c|}
\hline \multirow{2}{*}{ Parameter } & \multicolumn{2}{|c|}{ Point estimate } & \multicolumn{2}{|c|}{ Standard error } & \multicolumn{2}{|c|}{$\% \mathrm{CV}$} & \multicolumn{2}{|c|}{$95 \% \mathrm{Cl}$} \\
\hline & $\mathrm{A} 1$ & $\mathrm{~A} 2$ & $\mathrm{~A} 1$ & A2 & $\mathrm{A} 1$ & A2 & $\mathrm{A} 1$ & A2 \\
\hline$f(0)$ & 0.005 & 0.005 & 0.0005 & 0.0005 & 9.41 & 9.41 & $0.004-0.006$ & $0.004-0.006$ \\
\hline$P$ & 0.458 & 0.458 & 0.0430 & 0.0430 & 9.41 & 9.41 & $0.379-0.554$ & $0.379-0.554$ \\
\hline $\mathrm{ESW}(\mathrm{km})$ & 203.200 & 203.200 & 19.1190 & 19.1190 & 9.41 & 9.41 & $168-246$ & $168-246$ \\
\hline Encounter rate $(\mathrm{n} / \mathrm{l})$ & 0.031 & 0.044 & 0.0080 & 0.0110 & 25.35 & 24.98 & $0.018-0.051$ & $0.027-0.073$ \\
\hline Density of groups (groups $/ \mathrm{km}^{2}$ ) & 0.075 & 0.109 & 0.0200 & 0.0290 & 27.04 & 26.69 & $0.044-0.128$ & $0.063-0.185$ \\
\hline Average group size (s) & 4.219 & 4.218 & 0.5410 & 0.5410 & 12.82 & 12.82 & $3.256-5.466$ & $3.256-5.466$ \\
\hline Density of individuals & 0.318 & 0.459 & 0.0950 & 0.1360 & 29.93 & 29.61 & $0.178-0.570$ & $0.256-0.821$ \\
\hline Abundance & 50.000 & 47.000 & 14.9630 & 13.9170 & 29.93 & 29.61 & $28-89$ & $26-84$ \\
\hline
\end{tabular}

A1) Corresponds to the analysis for the study area $\left.\left(160 \mathrm{~km}^{2}\right) ; \mathrm{A} 2\right)$ corresponds to the analyses for the sub-areas of franciscana occurrence $\left(101 \mathrm{~km}^{2}\right)$.

the harbor activity, such as ship movement, that produces a strong underwater noise (NRC 2003). Franciscanas do not occur in the inner parts of the bay. Sub-area 4 has low salinity values (Oliveira et al. 2006) and it is possible that this parameter influence the distribution of preys. The animals were not registered also in the Lagoa do Saguaçú and Canal do Linguado region (inside sub-area 5), that are very impacted by industrial and domestic discharges from Joinville, and by a continuous silting process (Oliveira et al. 2006).

Density and abundance estimates of $P$. blainvillei population in concentration areas ( 0.46 individuals $\mathrm{km}^{-2}$ ) were lower than those found at the coast of the state of Rio Grande do Sul, Brazil, which was of 0.66 individuals $\mathrm{km}^{-2}$ (SECCHI et al. 2001). However, if franciscanas show a clumped distribution pattern along the coast, similar to that observed in Babitonga bay, it is not worth whereas to conduct simple extrapolation to obtain abundance estimates. Population abundance can be overestimated or underestimated with simple extrapolation of data.

Differences between density and abundance of small cetacean populations in different areas probably reflect differences in productivity and availability of prey, so as the effect of human impacts caused by overfishing, habitat degradation, contamination by chemicals and incidental mortality in fishing gear (BowEN \& SINIFF 1999). Babitonga bay is affected by all of these impacts, but the absence of population estimates for the species in other estuarine areas does not allow comparisons. Franciscana and estuarine dolphin populations share some prey items in Babitonga bay, and competition is also considered an important factor that affects population abundance (BEGON et al. 1996).

Franciscanas were never observed in the outer parts of the estuary (sub-area 1) but it is probable that movements in and out of the bay may occur. The high concentration in the innermost parts and year-round occurrence of the species inside the bay indicate that the population may have some level of fidelity regarding this area. Genetic studies for stock identification will be of great importance, considering the possibility of the existence of an isolated population in Babitonga bay.

\section{ACKNOWLEDGEMENTS}

This work would not be accomplished without the participation of the students F.A.S. Hardt, A.J. Tonello Jr, A. Marcucci and A. Herbst, nor without the financial support provided by the Universidade da Região de Joinville through their Fundo de Apoio À Pesquisa. Paulo C. Simões-Lopes was supported by Conselho Nacional de Desenvolvimento Científico e Tecnológico (PQ-II, process 304698/2006-7). We are grateful to IPE/CI that promoted the Quantitative Ecological course in 2003 and several anonymous reviewers for helpful comments on earlier versions of this manuscript.

\section{LITERATURE CITED}

BALLANCE, L.T. 1992. Habitat use patterns and ranges of bottlenosedolphin in the Gulf of California, Mexico. Marine Mammal Science 8 (3): 262-274.

Bearzi, M. 2005. Dolphins sympatric ecology. Marine Biology Research 1: 165-175.

Begon, M.; J.L. Harper \& C.R. Townsend. 1996. Ecology: individuals, populations and communities. Oxford, Blackwell Science, 1068p.

Bordino, P. 2002. Movement patterns of franciscana dolphins (Pontoporia blainvillei) in Bahia Anegada, Buenos Aires, Argentina. Latin American Journal of Aquatic Mammals 1 (1): 71-76.

Bordino, P.; G. Thompson \& M. Iñiguez. 1999. Ecology and behaviour of the franciscana (Pontoporia blainvillei) in Bahía Anegada, Argentina. Journal of Cetacean Research and Management 1 (2): 213-222.

Bowen, W.D. \& D.B. Siniff. 1999. Distribution, population biology, and feeding ecology of marine mammals, p. 423-484. In: J.E. Reynolds III \& S.A. Rommel (Eds). Biology of marine mammals. Washington, Smithsonian Institution Press, 578p.

BuCKLAND, S.T.; D.R. ANDERSON; K.P. BurnhaM; J.L. LAAKE; D.L. BORChERS \& L. Thomas. 2001. Introduction to Distance Sampling. Estimating abundance of biological populations. London, 
Oxford University Press, 448p.

Burnham, K.P.; D.R. Anderson \& J.L. Lake. 1980. Estimation of density from line transect sampling of biological populations. Wildlife Monographs 72: 1-202.

Cremer, M.J. \& P.C. Simões-Lopes. 2005. The occurrence of Pontoporia blainvillei (Gervais \& d'Orbigny) (Cetacea, Pontoporiidae) in an estuarine area in southern Brazil. Revista Brasileira de Zoologia 22 (3): 717-723.

Cremer, M.J.; F.A.S. Hardt; A.J. Tonello Júnior \& P.C. Simões-Lopes. 2004. Core areas changes in Sotalia guianensis (Cetacea, Delphinidae) population in Babitonga Bay, Santa Catarina. Revista UNIVILLE 9: 12-16.

Crespo, E.A.; G. Harris \& R. GonzÁLez. 1998. Group size and distributional range of the franciscana, Pontoporia blainvillei. Marine Mammal Science 14 (4): 845-849.

Di Beneditto, A.P.M.; R.M.A. Ramos \& N.R.W. Lima. 2001. Sightings of Pontoporia blainvillei (Gervais and D'Orbigny, 1844) and Sotalia fluviatilis (Gervais, 1853) (Cetacea) in South-eastern Brazil. Brazilian Archives of Biology and Technology 44 (3): 291-296.

Edwards, H.H. \& G.D. Schnell. 2001. Status and ecoloy os Sotalia fluviatilis in the Cayos Miskito Reserve, Nicaragua. Marine Mammal Science 17 (3): 445-472.

Hildebrand, J. 2005. Impacts of anthropogenic sound, p. 101123. In: J.E. Reynolds III; W.P. Perrin; R.R. ReEves; S. Montgomery \& T.J. Ragen (Eds). Marine mammal research: conservation beyond crisis. Baltimore, The Johns Hopkins University Press, $223 p$.

Iвама. 1998. Proteção e Controle de Ecossistemas Costeiros: manguezal da Baía de Babitonga. Brasília, Instituto Brasileiro do Meio Ambiente e dos Recursos Naturais Renováveis, $145 \mathrm{p}$.

Iвама. 2003. Lista da Fauna Brasileira Ameaçada de Extinção. Brasília, Instituto Brasileiro do Meio Ambiente e dos Recursos Naturais Renováveis, Instrução Normativa MMA 03/ 2003,.available online at: www.ibama.gov.br/fauna/extinção [Acessed in 18.I.2006]

Karczmarski, L.; V.G. Cockroft \& A. McLachlan. 2000. Habitat use and preferences of indo-pacific humpback dolphins Sousa chinensis in Algoa, south Africa. Marine Mammal Science 16: 65-79.

NRC. 2003. Ocean noise and marine mammals. Washington, National Research Council, The National Academic Press, 192p.

Oliveira, T.M.N.; C.R. Tureck; J.C. Bassfeld; B.M.O. Torrens; J.M. FARIA \& K. BRASIL. 2006. Integridade ambiental da Baía da Babitonga: características físico-químicas, microbiológicas e ecotoxicidade. In: M.J. Cremer; P.R.D. Morales \& T.M.N. Oliverra (Eds). Diagnóstico ambiental da Baía da Babitonga. Joinville, Editora da Univille, XIV+256p.
Pinedo, M.C. 1994. Impact of incidental fishery mortality on the age structure of Pontoporia blainvillei in southern Brazil and Uruguay. Report of the International Whaling Commission 15: 261-264.

Pinedo, M.C.; R. Praderi \& R.L. Brownell Jr. 1989. Review of the biology and status of the franciscana, Pontoporia blainvillei, p. 46-51. In: W.F. Perrin; R.L. Brownell JR; Z. Kaya \& L. JiAnkANG (Eds). Biology and Conservation of the River Dolphins. Gland, IUCN, 173p.

Praderi, R.; M.C. Pinedo \& E.A. Crespo. 1989. Conservation and management of Pontoporia blainvillei in Uruguai, Brasil and Argentina, p. 52-56. In: W.F. Perrin; R.L. Brownell JR; Z. KaYA $\&$ L. JIANKANG (Eds). Biology and Conservation of the River Dolphins. Gland, IUCN, 173p.

Reeves, R.R.; B.D. Smith; E. Crespo \& G. Notarbartolo di Sciara. 2003. Dolphins, whales and porpoises. 2002-2010 Conservation Action Plan for the world's cetaceans. Gland, IUCN, 139p.

Rosas, F.C.W.; E.L.A. Monteiro-Filho \& M.R. Oliveira. 2002. Incidental catches of franciscana (Pontoporia blainvillei) on the southern coast of São Paulo state and the coast of Paraná state, Brazil. Latin American Journal of Aquatic Mammals 1: 161-168.

Secchi, E.R.; P.H. Otт; E.A. Crespo; P.G. Kinas; S.N. Pedraza \& P. BoRDINO. 2001. A first estimate of franciscana (Pontoporia blainvillei) abundance off southern Brazil. Journal of Cetacean Research and Management 3: 95-100.

Shane, S.H. 1990. Behavior and ecology of the bottlenose dolphin at Sanibel island, Florida, p. 245-265. In: S. LEATHERWOod \& R.R. Reeves (Eds). The bottlenose dolphin. San Diego, Academic Press, 652p.

Siciliano, S. 1994. Review of small cetaceans and fishery interactions in coastal waters of Brazil. Reports of the Internatinal Whaling Commission 15: 241-250.

Thomas, L.; J.L. Laake; S. Strindberg; F.F.C. Marques; S.T. Buckland; D.L. Borchers; D.R. Anderson; K.P. Burnham; S.L. Hedley \& J.H. Pollard. 2002a. Distance 4.0 Release 1. St. Andrews, University of St. Andrews, available online at: http:// www.ruwpa.st-and.ac.uk/distance [Accessed in 18.I.2006]

Thomas, L.; S.T. Buckland; K.P. Burnham; D.R. Anderson; J.L. LAaKe; D.L. Borchers \& S. Strindberg. 2002b. Distance sampling, p. 544-552. In: A.H. El-ShaArawi \& W.W. Piegorsch (Eds). Encyclopedia of Environmetrics, Volume 1. Chichester, John Wiley \& Sons, 660p.

Trimble, M. \& R. Praderi. 2006. What is the color of the franciscana (Pontoporia blainvillei)?: a review and a proposed assessment method. Latin American Journal of Aquatic Mammals 5 (1): 55-63.

Würsig, B. \& M. Würsig. 1980. Behavior and ecology of dusky dolphins, Lagenorhynchus obscurus, in the south Atlantic. Fishery Bulletin 77: 871-891.

Submitted: 11.IX.2007; Accepted: 05.IX.2008.

Editorial responsibility: Lena Geise

Revista Brasileira de Zoologia 25 (3): 397-402, September, 2008 